\title{
Magnitude and Trends of High-elevation Cloud Water Pollutant Concentrations and Modeled Deposition
}

\section{Fluxes}

\author{
Selma Isil $1^{1}$, Thomas Lavery ${ }^{2}$, Kristi Gebhart ${ }^{3}$, Christopher Rogers ${ }^{1}$ and Carol Armbrust Wanta ${ }^{1}$ \\ 1. Amec Foster Wheeler Environment \& Infrastructure, Inc., Newberry, Florida 32669-3000, USA \\ 2. Air Quality Science, Cranston, Rhode Island 02920, USA \\ 3. U.S. National Park Service, Air Resources Division, Colorado State University, Fort Collins, Colorado 80523, USA
}

\begin{abstract}
Cloud water samples, LWC (Liquid Water Content) and meteorological data were collected at the Clingmans Dome, Tennessee, high-elevation site in Great Smoky Mountains National Park during the warm season from 1994 through 2011. This paper presents results from 2000 through the conclusion of the study in 2011. Samples were analyzed for $\mathrm{SO}_{4}{ }^{2-}, \mathrm{NO}_{3}{ }^{-}, \mathrm{NH}_{4}{ }^{+}$and $\mathrm{H}^{+}$. These measurements were supplemented by measurements of ambient air and precipitation concentrations to estimate dry and wet deposition. Cloud water concentrations, LWC, cloud frequency, various meteorological measurements and information on nearby forest canopy were used to model cloud water deposition to gauge trends in deposition. Total deposition was calculated as the sum of cloud, dry and wet deposition estimates. Concentrations and deposition fluxes declined over the study period. The decreases in cloud water $\mathrm{SO}_{4}{ }^{2-}$ and $\mathrm{NO}_{3}{ }^{-}$concentrations were 40 percent and 26 percent, respectively. Three-year mean $\mathrm{SO}_{4}{ }^{2-}$ and $\mathrm{NO}_{3}{ }^{-}$deposition rates decreased by 71 percent and 70 percent, respectively. Trends in concentrations and depositions were comparable with trends in $\mathrm{SO}_{2}$ and $\mathrm{NO}_{\mathrm{x}}$ emissions from Tennessee Valley Authority power plants and aggregated emission reductions from electric generating units in adjacent states. Back trajectories were simulated with the HYSPLIT model and aggregated over cloud sampling periods from 2000 through 2007 and 2009 through 2011. Trajectories during periods with high $\mathrm{H}^{+}$concentrations traveled over local EGU (Electric Generating Unit) emission sources in Tennessee and Kentucky to the Ohio River Valley, Alabama and Georgia with the conclusion that these source regions contributed to acidic cloud water deposition at Clingmans Dome. This work was supported by U.S. Environmental Protection Agency and the Tennessee Valley Authority with infrastructure support provided by the National Park Service.
\end{abstract}

Key words: Cloud water, acid deposition, liquid water content, emissions, back trajectory, high elevation.

\section{Introduction}

Atmospheric pollution is deposited to the environment via a number of physical and chemical mechanisms. In high-elevation environments, cloud and fog water samples are typically 5 to 20 times more acidic than rain water [1-5] and the interception of cloud water by spruce and fir trees and other vegetation in the Appalachian Mountains is a major deposition pathway [6-9]. Authors have concluded that deposition of pollutants by cloud water exceeds

Corresponding author: Selma Isil, master, senior scientist, main research field: occult deposition. deposition by precipitation and dry deposition in high elevation settings from North Carolina to Maine [2]. The large loading of pollutants in such environments is due to a combination of factors such as high frequency of cloud immersion, high wind speeds, orographic enhancement of precipitation and large leaf areas of tree species typical of these environments [10]. The decline of red spruce (Picea rubens) in the northeastern United States in the late 1980s was in part attributed to the reduction in cold tolerance by these species as a result of exposure to acidic cloud water [11]. Even at low elevations, deposition of pollutants by acidic fog is a contributor to pollution 
exposure as demonstrated by the Great Smog of 1952 in London during early December that killed thousands [12].

The MADPro (Mountain Acid Deposition Program) began in 1993 as part of the U.S. EPA's (Environmental Protection Agency's) CASTNET (Clean Air Status and Trends Network) and operated through September 2011. MADPro data contributed to meeting CASTNET's objective of determining the status and trends in air quality and pollutant deposition and the relationships among emissions, air quality and ecological effects by updating and extending the cloud water concentration and deposition data collected by the Mountain Cloud Chemistry Project during the NAPAP (National Acid Precipitation Assessment Program) of the 1980s [3, 5, 13-15] and by modeling cloud pollutant deposition through 2011.

This paper presents information on the magnitude and trends in cloud water S (Sulfur) and N (Nitrogen) pollutant concentrations and cloud, wet and dry deposition of $\mathrm{S}$ and $\mathrm{N}$ pollutants for the period 2000 through 2011. Previous results from Clingmans Dome and other MADPro sites are summarized in MADPro annual reports (e.g., [1]; https://java.epa.gov/castnet/documents.do) as well as in other publications (e.g., [2]). The trends in concentration measurements and in the deposition of concentrations were compared with trends in $\mathrm{SO}_{2}$ (Sulfur Dioxide) and $\mathrm{NO}_{\mathrm{x}}$ (Nitrogen Oxides) emissions from the TVA (Tennessee Valley Authority) power plants and aggregated emissions from power plants in adjacent states. Both the concentration and deposition trends, at least qualitatively, follow the trends in EGU (Electric Generating Unit) emissions.

Although this study concluded in 2011, there is a current need for concentration and deposition estimates from cloud water exposure. Over the past two decades, interest in better understanding of atmospheric inputs of pollutants to terrestrial and aquatic ecosystems has increased substantially within the scientific community through the use of the "critical load" approach. A critical load is technically defined as, "the quantitative estimate of an exposure to one or more pollutants below which significant harmful effects on specified sensitive elements of the environment are not expected to occur according to present knowledge" [16, 17]. Critical loads are developed using empirical as well as mass balance approaches. Both steady state models and dynamic models are used in the mass balance approach and deposition data are used in both types of models. In order to develop scientifically defensible critical loads estimates, it is essential to be able to estimate the total deposition to an ecosystem. Current scientific efforts have identified occult deposition as a "need" by the NADP's (National Atmospheric Deposition Program's), TDEP (Total Deposition Science Committee) as well as the CLAD (Critical Loads of Atmospheric Deposition Science Committee) in developing critical loads for ecosystems that experience significant cloud impaction $[18,19]$.

\section{Materials and Methods}

Clingmans Dome, Tennessee $\left(35^{\circ} 33^{\prime} 47^{\prime \prime} \mathrm{N}\right.$, $\left.83^{\circ} 29^{\prime} 55^{\prime \prime} \mathrm{W}\right)$ is the highest mountain summit $(2,025$ $\mathrm{m})$ in the Great Smoky Mountains National Park. Cloud water samples were collected at Clingmans Dome (site ID CLD303) at an elevation of 2,014 m, approximately $100 \mathrm{~m}$ southeast of the summit tourist observation tower, during the warm season (usually May through October) and analyzed for their pollutant constituents. Weekly ambient pollutant concentrations were measured using a 3-stage, open face filter pack at the nearby CASTNET site (site ID GRS420) located to the west of CLD303 at a lower elevation in the park. Wet deposition data were obtained from the NADP/NTN (National Trends Network) site at Elkmont, Tennessee (site ID TN11) to the north of CLD303. Fig. 1 shows the locations of the three sites. Cloud water pollutant concentrations, cloud LWC (Liquid Water Content) and their frequencies together 


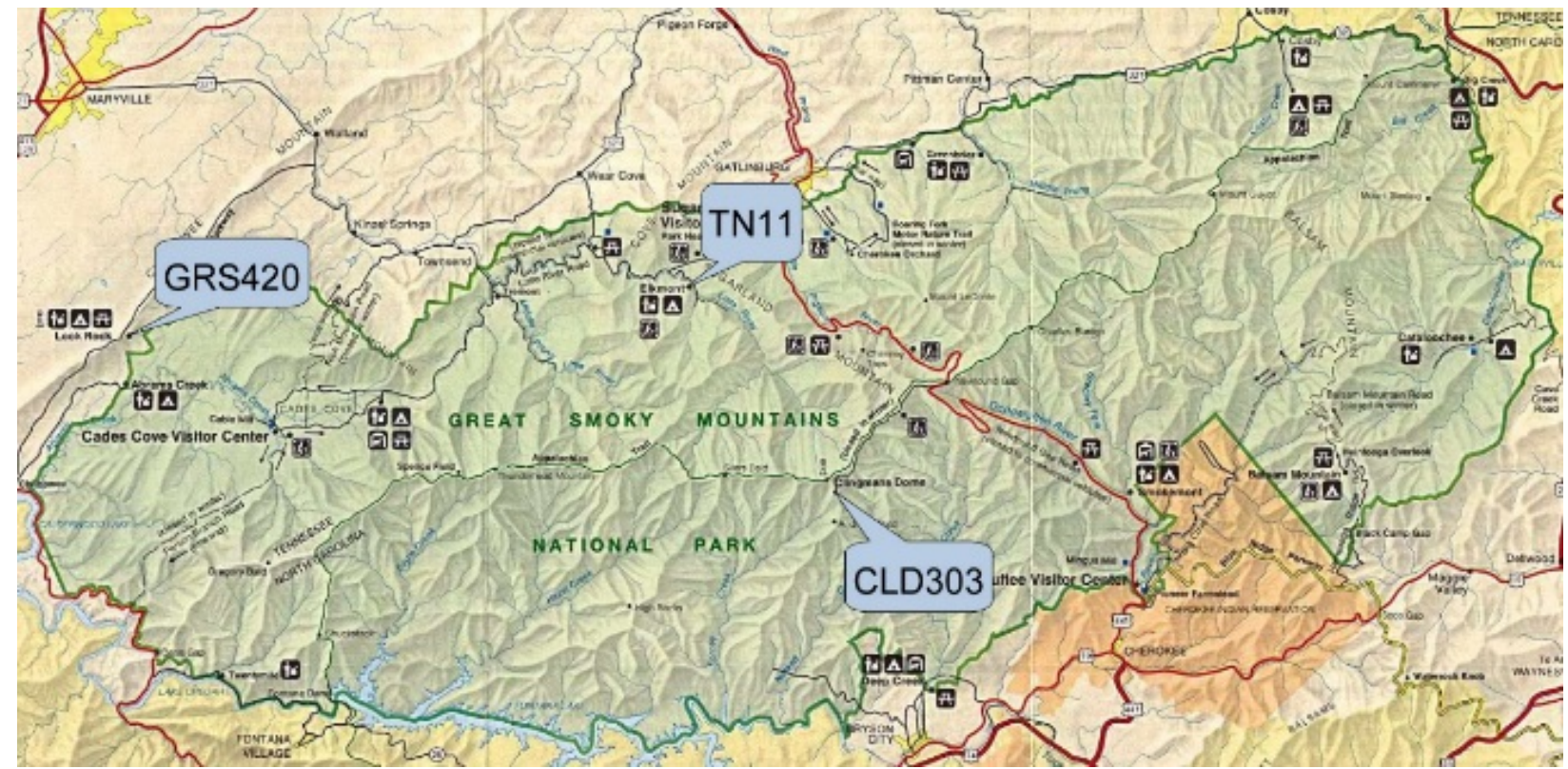

Fig. 1 CLD303 is the location of the Clingmans Dome cloud water-sampling site in Tennessee. GRS420 is the CASTNET filter pack site and TN11 is the NADP/NTN-protocol wet deposition site. All three sampling sites are located within or adjacent to Great Smoky Mountains National Park.

with various meteorological measurements were used to estimate cloud deposition of the pollutants. LWC was measured using a Gerber PVM-100 (Gerber Particle Volume Monitor-100). Cloud deposition was modeled using the CLOUD model [20]. Dry deposition was estimated using the MLM (Multi-Layer Model) $[21,22]$. Electronic instrumentation was housed in a small NPS (National Park Service) building and the cloud water collector, particle volume monitor and meteorological sensors were positioned atop a 50-foot scaffold tower (Fig. 2).

Total deposition was estimated as the sum of cloud, wet and dry deposition fluxes. Wet deposition data were provided by NADP/NTN from the TN11 measurements, and dry deposition data were modeled using CASTNET GRS420 measurements.

\subsection{Field Measurements}

The cloud collection system consisted of an automated cloud water collector for bulk cloud water sampling, a particle volume monitor for continuous determination of cloud LWC and cloud frequency and a data acquisition system for collection and storage of electronic information from the various monitors and sensors. Cloud water samples were collected daily. Additional information on the history of the CLD303 sampling strategies can be found in the MADPro annual reports (https://java.epa.gov/castnet/documents.do).

NPS operated meteorological instruments on an adjacent sampling tower that provided input (e.g., scalar wind speed) to the CLOUD deposition model. Filter pack ambient concentration data were collected at CLD303 through 2005. For the sake of consistency, however, all data for dry deposition analyses for 2000 through 2011 were obtained from GRS420, located 26 miles west, northwest of the CLD303 sampling site. Precipitation deposition measurements were taken at TN11.

The core of the automated cloud collection system (Fig. 2) was a passive string collector previously used in the Mountain Cloud Chemistry Project study. The development and design of the original system is described in detail [23].

The PVM-100 by Gerber, H. [24] measures LWC and effective droplet radius of ambient clouds by directing a diode-emitted 780-nanometer wavelength 


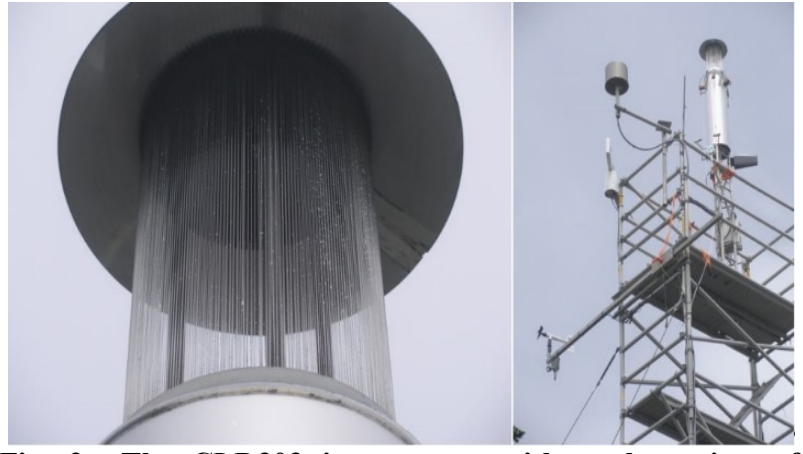

Fig. 2 The CLD303 instruments with a close view of extended cloud collector (left) and view of tower with cloud collector, particle volume monitor and meteorological instruments (right).

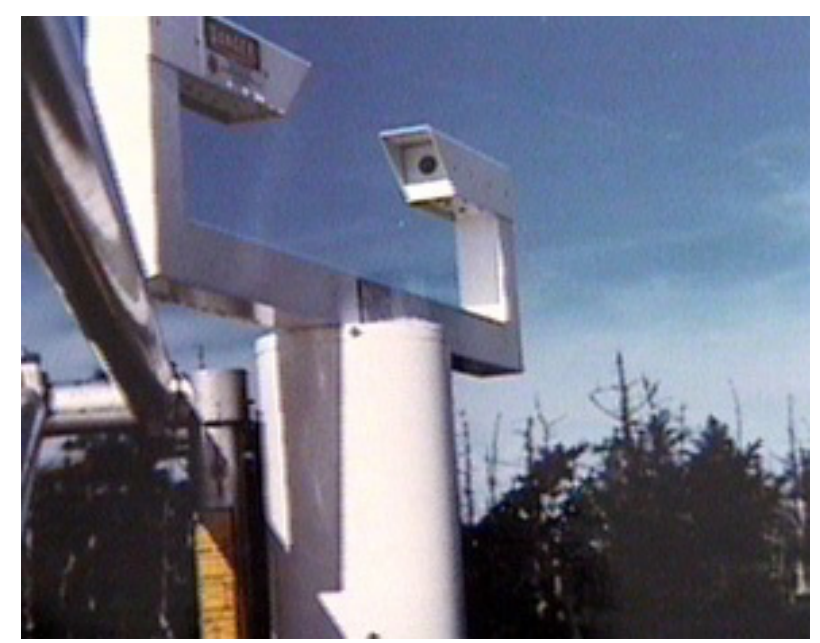

Fig. 3 The Gerber PVM-100 by Gerber, H. [24] measures LWC and effective droplet radius of ambient clouds by directing a diode-emitted laser beam along a 40-cm path. The forward scatter of the cloud droplets in the open air along the path is measured, translated and expressed as water in grams per cubic meter of air.

laser beam along a 40-centimeter (cm) path (Fig. 3). The forward scatter of the cloud droplets in the open air along the path is measured, translated and expressed as water in grams per cubic meter $\left(\mathrm{g} / \mathrm{m}^{3}\right)$ of air. The data logger was programmed so that the collector was activated and projected out of the protective housing when threshold levels for LWC $\left(0.05 \mathrm{~g} / \mathrm{m}^{3}\right)$ and ambient air temperature $\left(\geq 2{ }^{\circ} \mathrm{C}\right)$ were reached. Within the context of MADPro, a cloud was defined by a LWC of $0.05 \mathrm{~g} / \mathrm{m}^{3}$ or higher, as measured by the particle volume monitor. In addition, the system was activated only when no precipitation was measured.

\subsection{Laboratory Analyses}

Cloud water samples were analyzed for sodium $\left(\mathrm{Na}^{+}\right)$, potassium $\left(\mathrm{K}^{+}\right)$, ammonium $\left(\mathrm{NH}_{4}{ }^{+}\right)$, calcium $\left(\mathrm{Ca}^{2+}\right)$, magnesium $\left(\mathrm{Mg}^{2+}\right)$, chloride $\left(\mathrm{Cl}^{-}\right)$, nitrate $\left(\mathrm{NO}_{3}{ }^{-}\right)$and sulfate $\left(\mathrm{SO}_{4}{ }^{2-}\right)$ ions in the CASTNET laboratory in Gainesville, Florida. All samples were analyzed for $\mathrm{pH}$ and conductivity in the field and in the laboratory for comparison with the field values. Concentrations of the three anions $\left(\mathrm{SO}_{4}{ }^{2-}, \mathrm{NO}_{3}{ }^{-}\right.$and $\mathrm{Cl}^{-}$) were determined by micromembrane-suppressed ion chromatography. Analysis of samples for $\mathrm{Na}^{+}$, $\mathrm{Mg}^{2+}, \mathrm{Ca}^{2+}$ and $\mathrm{K}^{+}$was performed with a Perkin-Elmer Optima 7300 Dual View inductively coupled argon plasma-atomic emission spectrometer. The automated indophenol method using a Bran + Luebbe Autoanalyzer 3 was used to determine $\mathrm{NH}_{4}^{+}$ concentrations. The discussion in this paper focuses on $\mathrm{SO}_{4}{ }^{2-}, \mathrm{NO}_{3}{ }^{-}, \mathrm{NH}_{4}{ }^{+}$and $\mathrm{H}^{+}$.

Filter packs contain three filter types in sequence: a Teflon filter for collection of aerosols, a nylon filter for collection of $\mathrm{HNO}_{3}$ (Nitric Acid) and $\mathrm{SO}_{2}$ and dual potassium carbonate-impregnated cellulose filters for collection of $\mathrm{SO}_{2}$. Atmospheric concentrations derived from filter extracts were calculated based on the volume of air sampled following validation of the hourly flow data. Following receipt from the field, exposed filters and unexposed blanks were extracted and analyzed for $\mathrm{SO}_{4}{ }^{2-}, \mathrm{NO}_{3}{ }^{-}, \mathrm{Cl}^{-}$and the cations, $\mathrm{NH}_{4}^{+}, \mathrm{Na}^{+}, \mathrm{Mg}^{2+}, \mathrm{Ca}^{2+}$ and $\mathrm{K}^{+}$, as described previously for cloud water samples. Filter pack samples were loaded, shipped, received, extracted and analyzed at the CASTNET laboratory. For specific extraction procedures refer to the descriptions in Anlauf, K. G. et al. [25] and the CASTNET QAPP (Quality Assurance Project Plan) [26]. Atmospheric concentrations of particulate $\mathrm{SO}_{4}{ }^{2-}, \mathrm{NO}_{3}{ }^{-}, \mathrm{NH}_{4}{ }^{+}, \mathrm{Na}^{+}$, $\mathrm{Mg}^{2+}, \mathrm{Ca}^{2+}, \mathrm{K}^{+}$and $\mathrm{Cl}^{-}$were calculated based on analysis of Teflon filter extracts. $\mathrm{HNO}_{3}$ was calculated based on the $\mathrm{NO}_{3}{ }^{-}$measured in the nylon filter extracts. Some $\mathrm{SO}_{2}$ was trapped by the nylon filter; therefore, $\mathrm{SO}_{2}$ was calculated based on the sum of $\mathrm{SO}_{4}{ }^{2-}$ found 
in nylon and cellulose filter extracts. The CASTNET QAPP [26] provides detailed descriptions of laboratory receipt, breakdown, storage, extraction, analytical procedures and quality control requirements.

\subsection{Data Management}

Continuous data (temperature, precipitation, LWC and cloud collector status information) were collected in 5-minute and hourly averages. Hourly data were collected daily via internet protocol-based polling. The hourly data and associated status flags were ingested into Microsoft Excel spreadsheets. The particle volume monitor/LWC data were validated based on the end-of-season calibration results, periodic calibration check results and information provided by status flags and logbook entries.

Cloud water sample and filter pack sample results were managed by Element, the laboratory information management system [26]. In Element, the analytical batches were processed through an automated quality control check routine. For cloud water samples, an additional check involved calculating the percent difference of cations versus anions (ion balance), which provided another diagnostic for determining whether the analysis should be repeated or verified.

\subsection{Cloud Water Deposition Modeling}

Cloud pollutant deposition was estimated by applying the CLOUD model [20, 27] using site-specific cloud water chemistry and meteorological data from CLD303. The CLOUD model uses an electrical resistance network analogy to model the deposition of cloud water to forest canopies. The model is one-dimensional, assuming vertical mixing of droplet-laden air into the canopy from the top. Turbulence mixes the droplets into the canopy space where they cross the boundary layers of canopy tissues by impaction and sedimentation. Sedimentation rates are provided as a function of droplet size. Impaction efficiencies are related to the Stokes number, which integrates droplet size, obstacle size and wind speed [20]. The Stokes number is based on wind tunnel measurements by Thorne, P. G. et al. [28]. The model was tested against field data and was found to calculate cloud water deposition rates in good agreement with measured values. The model has been used extensively to simulate cloud water and pollutant deposition to forest canopies.

The forest canopy is modeled as stacked 1-meter layers containing specified amounts of various canopy tissues such as leaves, twigs and trunks. Wind speed at any height within the canopy space is determined based on the above-canopy wind speed and an exponential decline of wind speed as a function of downward-cumulated canopy surface area. The wind speed determines the efficiency of mixing of air and droplets into the canopy and also the efficiency with which droplets impact onto canopy surfaces. The model is deterministic and assumes a steady state, so that for one set of above-canopy conditions it calculates one deposition rate. The model requires as input data the surface area index of canopy tissues in each height layer in the canopy, the zero-plane displacement height and roughness length of the canopy, wind speed at the canopy top, LWC of the cloud above the canopy and the mode of the droplet diameter distribution in the cloud [20]. Model runs were made assuming a $10-\mathrm{m}$ tall, intact, homogeneous conifer canopy. The actual canopy structure at Clingmans Dome has not been quantified and may differ substantially from the modeled canopy structure Cloud events with valid wind speed, cloud LWC and event duration data were used for the modeling for approximately 42 events for each cloud season.

From these input parameters, the model calculates the deposition of cloud water expressed both as a water flux rate in grams per square centimeter per minute $\left(\mathrm{g} / \mathrm{cm}^{2} / \mathrm{min}\right)$ and as a deposition velocity (flux rate $/ \mathrm{LWC})$ in units of centimeters per second $(\mathrm{cm} / \mathrm{s})$. Deposition rates of pollutants are calculated by 
multiplying the water deposition velocity by the pollutant concentration in cloud water above the canopy. After the model was run for all cloud events, seasonal (June through September) and monthly means and totals were calculated.

\subsection{Dry Deposition Modeling}

Dry deposition processes were modeled as resistances to deposition. The original CASTNET design was based on the assumption that dry deposition or flux could be estimated as the linear product of measured pollutant $\mathrm{C}$ (Concentration) and modeled $V_{d}$ (Deposition Velocity) where $V_{d}$ is influenced by meteorological conditions, vegetation and atmospheric and plant chemistry. The $\mathrm{V}_{\mathrm{d}}$ values for each site are calculated for each hour of each year using the MLM. The MLM was summarized [21, 22]. The data used in the MLM to estimate dry deposition were derived from meteorological measurements and pollutant concentrations taken at GRS420 together with an estimation of the vegetation leaf-out and LAI (Leaf Area Index).

\subsection{Quality Assurance}

The QA (Quality Assurance) program consisted of the same audits performed for CASTNET measurements, if applicable, and testing/comparison of instruments unique to cloud water sampling. QA procedures are documented in detail in the MADPro QA Plan, which is Appendix 10 to the CASTNET QAPP [26]. The CASTNET QAPP was designed to ensure that all reported data are of known and documented quality in order to meet CASTNET objectives and to be reproducible and comparable with data from other monitoring networks and laboratories. CASTNET utilizes DQI (Data Quality Indicators) to interpret the degree of acceptability and utility of the measured cloud water and related data. The DQI for CASTNET are precision, accuracy, bias, completeness, representativeness and comparability. The DQI results demonstrated the MADPro measurements met the project QC requirements.

\section{Analysis and Results}

This section provides a summary of the several measurements taken at CLD303, a comparison of field measurement data from CLD303 and the cloud monitoring site at Whiteface Mountain, New York (site ID WFM300), CLOUD model simulations of cloud water pollutant deposition at CLD303, estimates of total (cloud, wet and dry) deposition, a comparison of changes in cloud pollutant deposition compared with changes in emissions from TVA EGUs and from power plants in nearby states and some example backward trajectory analyses estimated from wind measurements for periods with low and high cloud water pollutant concentrations.

\subsection{Cloud Frequency, LWC and Precipitation}

Cloud LWC was measured hourly using the PVM-100 in order to estimate cloud water deposition and provide input to the CLOUD model. The LWC value also defined when the site was in cloud and, consequently, the cloud frequency at the site. Seasonal (June through September) cloud frequencies for Clingmans Dome were determined by calculating the relative percent of all hourly LWC values equal to or greater than $0.05 \mathrm{~g} / \mathrm{m}^{3}$, or:

$$
C F=\frac{100^{*}\left(\# \text { of valid hourly } L W C \text { values } \geq 0.05 \mathrm{~g} / \mathrm{m}^{3}\right)}{\mathrm{n}}
$$

Where, $n$ is the number of valid hourly LWC values per season and $C F$ is cloud frequency.

Cloud frequencies varied substantially from month-to-month and year-to-year. Fig. 4 presents the mean seasonal (June through September) cloud frequency statistics from 2000 through 2011 and illustrates the wide range of cloud frequency values from the minimum value of 27 percent in 2010 to the maximum value of 56 percent for 2001. Fig. 5 shows seasonal LWC and precipitation values from 2000 through 2011. Sampling did not occur during 2008, 


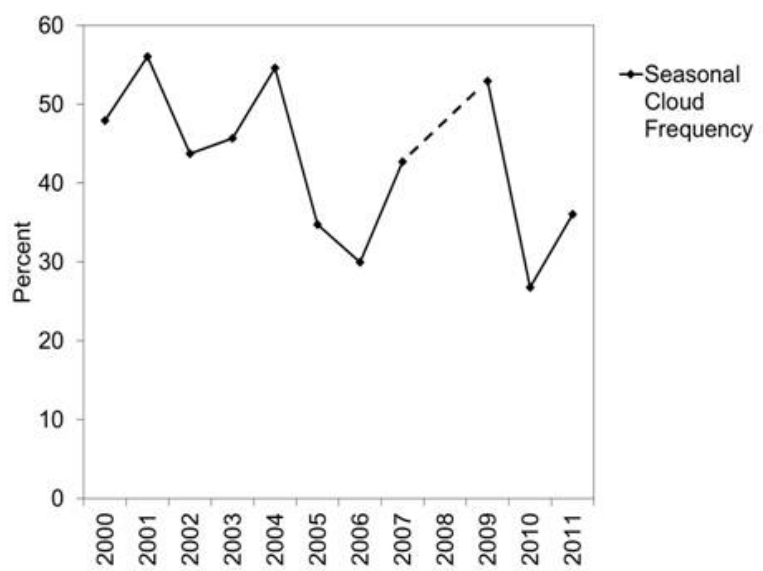

Fig. 4 Mean seasonal (June through September) cloud frequency at CLD303, 2000-2011.

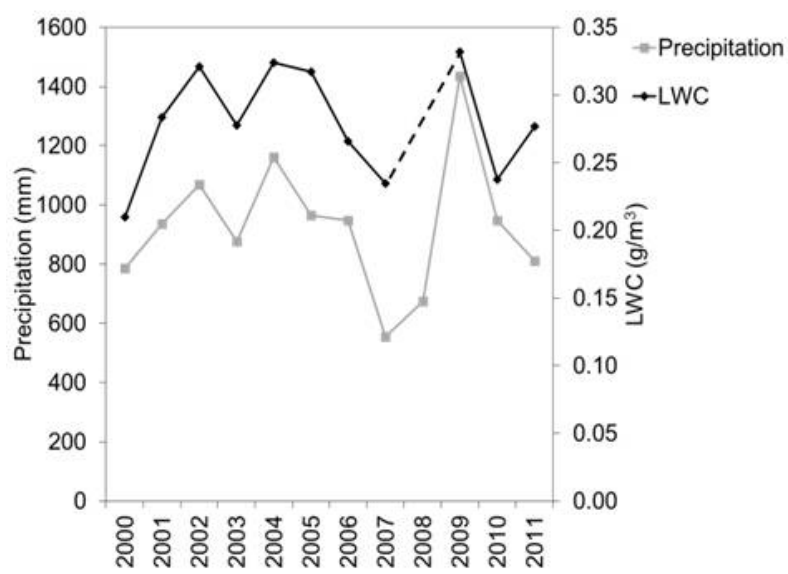

Fig. 5 Mean seasonal (June through September) LWC and precipitation, 2000-2011.

and, therefore, data are interpolated using 2007 and 2009 values. $\mathrm{LWC}$ varied from $0.21 \mathrm{~g} / \mathrm{m}^{3}$ in 2000 to $0.33 \mathrm{~g} / \mathrm{m}^{3}$ in 2009 . The highest precipitation occurred in 2009 with an amount of 1,434 millimeters (mm). The lowest $(555 \mathrm{~mm})$ was measured in 2007. The precipitation rates varied over a factor of 2.6 range. The seasonal LWC measurements varied similarly on an annual basis to the precipitation rates, but with a smaller factor of 1.65 range over the 12 years.

\subsection{Cloud Water Chemistry}

Mean concentrations in microequivalents per liter ( $\mu \mathrm{eq} / \mathrm{L})$ from the onset of the project through 2011 for $\mathrm{SO}_{4}{ }^{2-}$, hydrogen $\left(\mathrm{H}^{+}\right), \mathrm{NH}_{4}{ }^{+}$and $\mathrm{NO}_{3}^{-}$, are presented in Fig. 6. The concentrations follow approximately the same pattern of increases and decreases with respect

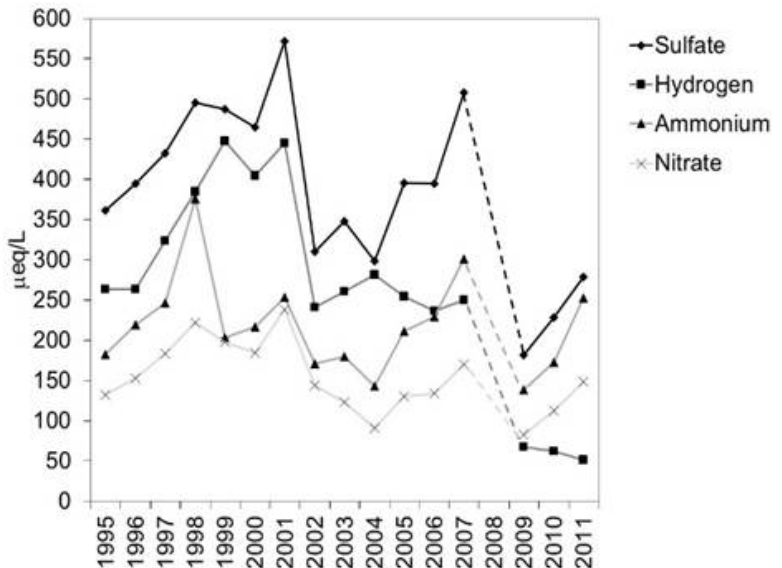

Fig. 6 Mean major ion concentrations of cloud water samples, 1995-2011.

to each other with a few exceptions. In general, after a period of increase from 1995 to 2001, the major ion concentrations in cloud water decreased, except for a 3-year period from 2005 through 2007 when all concentrations, except for $\mathrm{H}^{+}$, increased. Concentrations declined after 2007. However, since samples were not collected in 2008, the concentrations for 2008 are unknown. In any event, 3-year mean concentrations of $\mathrm{SO}_{4}{ }^{2-}, \mathrm{NO}_{3}{ }^{-}$and $\mathrm{H}^{+}$for 2009 through 2011 were lower $(229.67,114.70$ and $60.09 \mu \mathrm{eq} / \mathrm{L}$, respectively) than 3-year mean concentrations measured for 1995 through 1997 (396.14, 156.16 and $283.61 \mu \mathrm{eq} / \mathrm{L}$, respectively).

Seasonal (June through September) mean cloud water concentrations of $\mathrm{SO}_{4}{ }^{2-}$ and $\mathrm{NO}_{3}{ }^{-}$were compared to seasonal mean precipitation concentrations of $\mathrm{SO}_{4}{ }^{2-}$ and $\mathrm{NO}_{3}{ }^{-}$. The precipitation concentration data were obtained from the TN11 NADP/NTN site. The following discussion will focus on cloud water and precipitation data from the period 2000 through 2011.

Figs. 7 and 8 present the comparisons for $\mathrm{SO}_{4}{ }^{2-}$ and $\mathrm{NO}_{3}{ }^{-}$, respectively. Precipitation concentrations follow the same general pattern of increases and decreases as the cloud water concentrations, especially from 2004. Three-year mean concentrations in cloud water and in precipitation were lower in 2009-2011 than in 2000-2002 by approximately 45 and 37 percent for cloud water $\mathrm{SO}_{4}{ }^{2-}$ and $\mathrm{NO}_{3}{ }^{-}$and by 49 percent and 31 percent for precipitation $\mathrm{SO}_{4}{ }^{2-}$ and $\mathrm{NO}_{3}{ }^{-}$. 


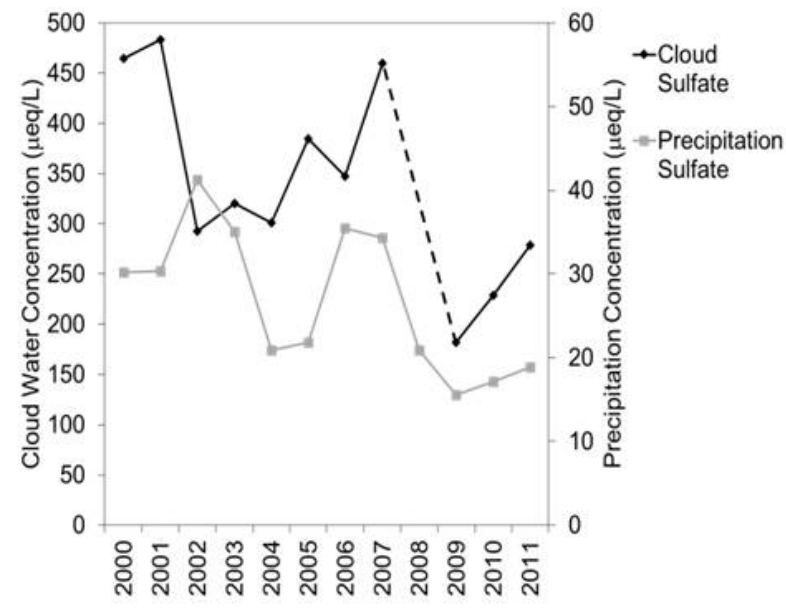

Fig. 7 Mean seasonal (June through September) cloud water versus mean seasonal precipitation sulfate concentrations, 2000-2011.

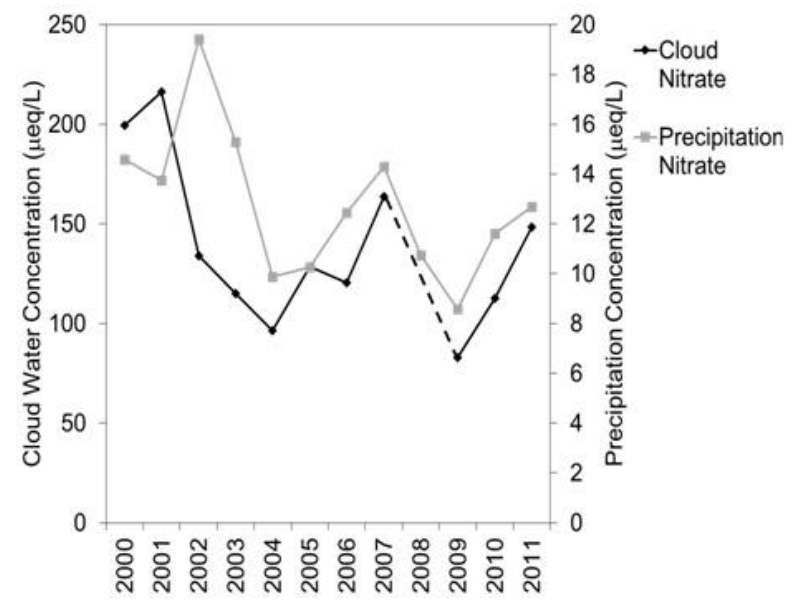

Fig. 8 Mean seasonal (June through September) cloud water versus mean seasonal precipitation nitrate concentrations, 2000-2011.

\subsection{Comparison with Cloud Water Pollutant} Concentrations Collected at WFM300

Cloud water pollutant concentrations, LWC and related measurements were collected at WFM300 from 1994 through 2001 under MADPro. Since 2001, the WFM300 site has been sponsored by the New York State Department of Environmental Conservation and operated by the Adirondack Lake Survey Corporation. Data from CLD303 and WFM300 [29] are available for the years 2000 through 2011. LWC and $\mathrm{SO}_{4}{ }^{2-}$ and $\mathrm{NO}_{3}{ }^{-}$concentrations for both sites are shown in Figs. 9-11.

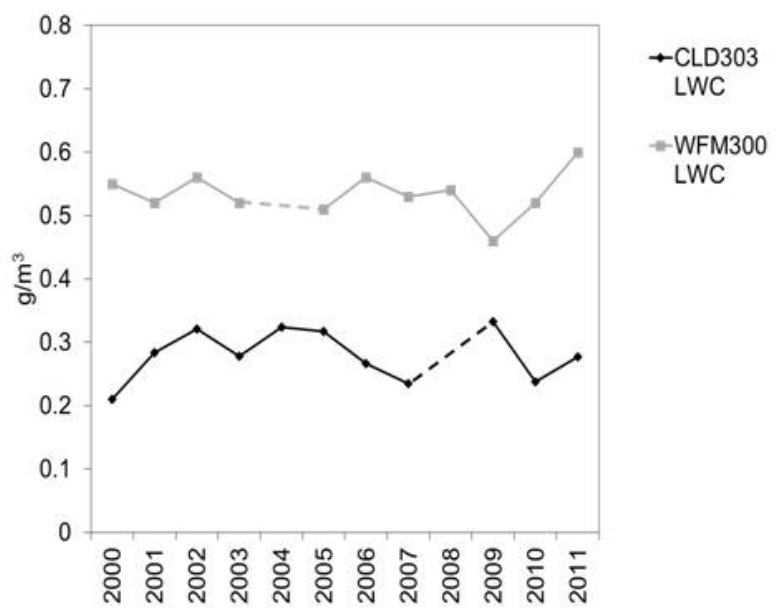

Fig. 9 Mean seasonal (June through September) LWC for CLD303 and WFM300, 2000-2011.

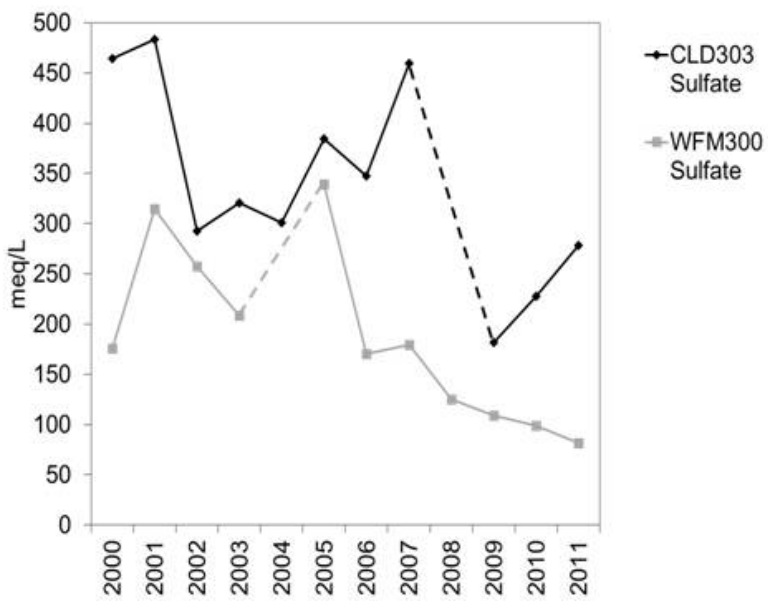

Fig. 10 Mean seasonal (June through September) cloud water sulfate concentrations for CLD303 and WFM300, 2000-2011.

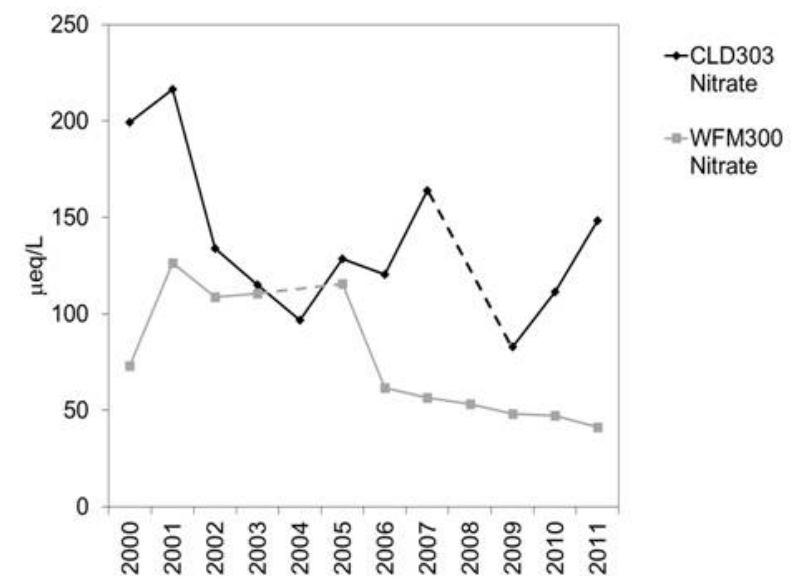

Fig. 11 Mean seasonal (June through September) cloud water nitrate concentrations for CLD303 and WFM300, 2000-2011. 
Fig. 9 shows that seasonal LWC values at WFM300 were consistently higher than the seasonal LWC values at CLD303. The 12-year average (2000 through 2011) value of $0.534 \mathrm{~g} / \mathrm{m}^{3}$ at WFM 300 was almost twice as high as the average value of $0.280 \mathrm{~g} / \mathrm{m}^{3}$ at CLD303. Higher LWC values usually result in greater water deposition to surrounding ecosystems. Cloud pollutant deposition depends on pollutant concentrations in cloud water, LWC and several other parameters.

Seasonal LWC values at CLD303 were consistently lower than LWC values for WFM300 resulting in consistently higher concentrations measured at the CLD303 site. Seasonal $\mathrm{SO}_{4}{ }^{2-}$ concentrations from 2000 through 2011 are presented in Fig. 10. Yearly variations in concentrations at both sites were considerable. Sulfate concentrations were consistently higher at CLD303 with an average seasonal concentration of $340.1 \mu \mathrm{eq} / \mathrm{L}$ compared with 187.3 $\mu \mathrm{eq} / \mathrm{L}$ at WFM300. Both sites experienced an overall downward trend from 2000 through 2011. The decrease in $\mathrm{SO}_{4}{ }^{2-}$ concentrations was 40 percent at CLD303 and 54 percent at WFM300.

Seasonal $\mathrm{NO}_{3}^{-}$concentrations for 2000 through 2011 are presented in Fig. 11. Nitrate concentrations were consistently higher at CLD303 with an average seasonal concentration of $137.9 \mu \mathrm{eq} / \mathrm{L}$ at CLD303 versus $76.6 \mu \mathrm{eq} / \mathrm{L}$ at WFM300. The CLD303 average was 45 percent higher than the WFM300 level. Overall, downward trends were observed at both sites from 2000 through 2011. The decrease in $\mathrm{NO}_{3}{ }^{-}$ concentrations was 26 percent at CLD303 and 44 percent at WFM300.

\subsection{Cloud Water Pollution Deposition}

Cloud water deposition was estimated by using the CLOUD model [20] parameterized with site-specific cloud water chemistry, LWC and wind speed data from CLD303 for 1999 through 2007 and 2009 through 2011. MADPro annual reports at https://java.epa.gov/castnet/documents.do under "Cloud Deposition" and MADPro: Cloud Deposition to the Appalachian Mountains, 1994-1999 [2] provide detailed descriptions of the CLOUD model and related modeling/analysis procedures.

Data sets from 2000 through 2007 and 2009 through 2011 were sufficiently complete to estimate a seasonal (June through September) deposition value. Deposition data from three of the four months were required to calculate the seasonal deposition. Fig. 12 presents the seasonal deposition estimates in kilograms per hectare $(\mathrm{kg} / \mathrm{ha})$ for the major ions from 2000 through 2007 and from 2009 through 2011. The plots depict an overall decrease in seasonal deposition estimates. For example, $\mathrm{SO}_{4}{ }^{2-}, \mathrm{NO}_{3}^{-}, \mathrm{NH}_{4}^{+}$and $\mathrm{H}^{+}$ 3 -year mean deposition rates decreased by 71 percent $(67.9 \mathrm{~kg} / \mathrm{ha}$ versus $19.6 \mathrm{~kg} / \mathrm{ha}), 70$ percent $(42.1 \mathrm{~kg} / \mathrm{ha}$ versus $12.6 \mathrm{~kg} / \mathrm{ha}), 49$ percent $(11.7 \mathrm{~kg} / \mathrm{ha}$ versus 6.0 $\mathrm{kg} / \mathrm{ha})$, and 88 percent $(1.1 \mathrm{~kg} / \mathrm{ha}$ versus $0.13 \mathrm{~kg} / \mathrm{ha})$, respectively, from 2000-2002 to 2009-2011.

Wet deposition data from 1995 through 2011 were obtained from the NADP/NTN site TN11 (Fig. 1). The deposition fluxes produced by precipitation were compared to cloud water deposition rates for 2000 through 2007 and 2009 through 2011. Figs. 13 and 14 show the seasonal $\mathrm{SO}_{4}{ }^{2-}$ and $\mathrm{NO}_{3}{ }^{-}$deposition estimates, respectively, for both cloud water and precipitation data. The cloud water deposition estimates are plotted against the left y-axis, and the wet deposition values

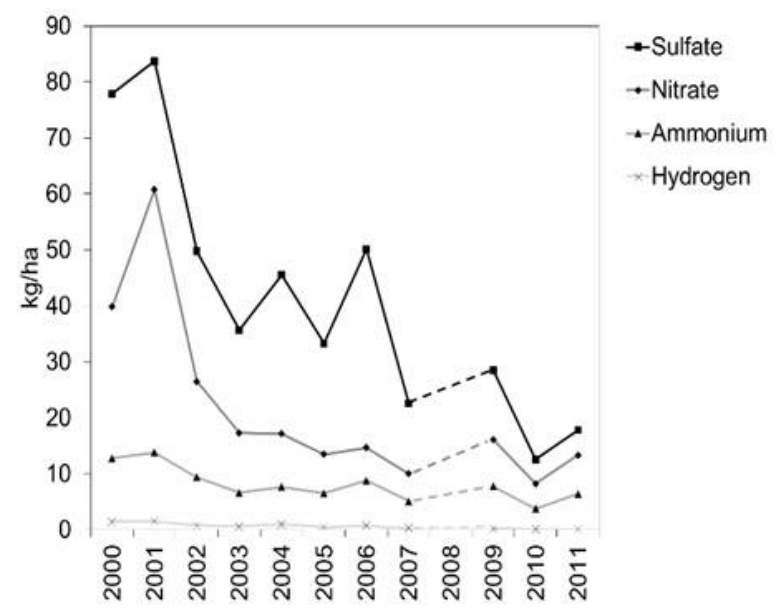

Fig. 12 Seasonal (June through September) deposition estimates for major ions in cloud water at CLD303, 2000-2011. 


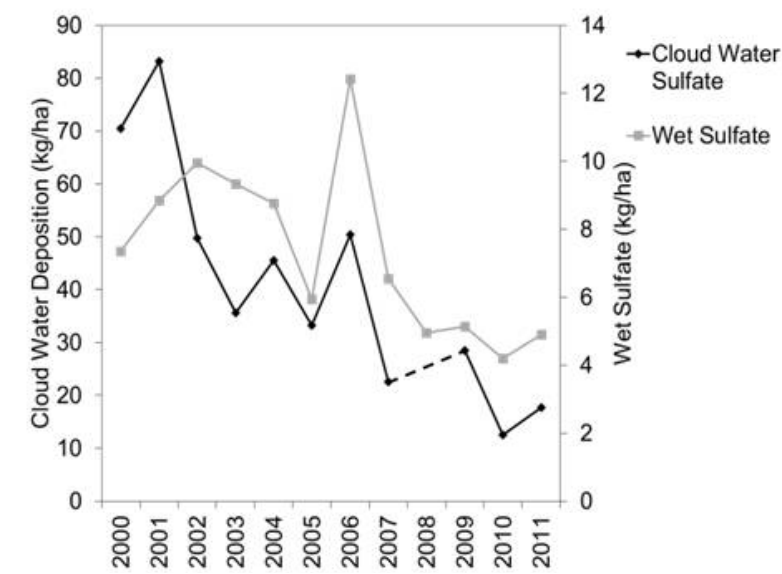

Fig. 13 Seasonal (June through September) cloud water and wet sulfate deposition estimates for CLD303, 2000-2011.

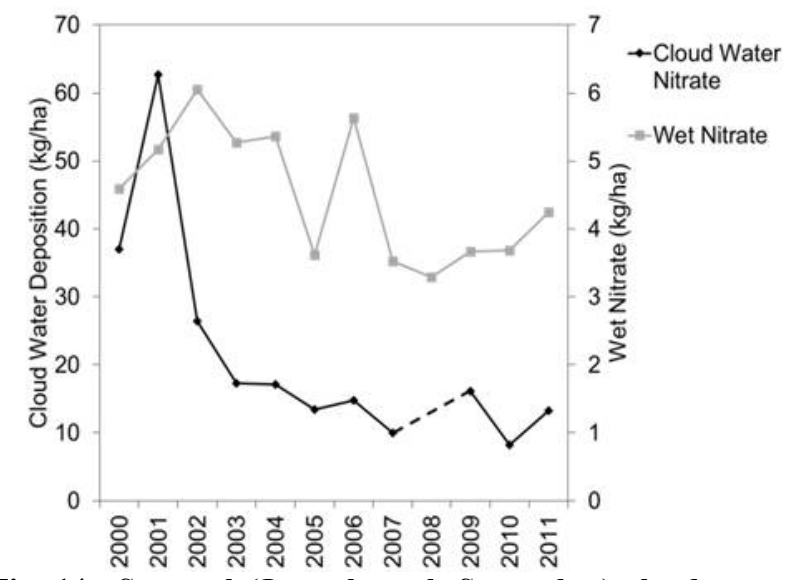

Fig. 14 Seasonal (June through September) cloud water and wet nitrate deposition estimates for CLD303, 2000-2011.

are plotted against the right y-axis. Starting in 2004, cloud water and wet $\mathrm{SO}_{4}{ }^{2-}$ deposition followed a similar pattern.

\subsection{Total Deposition}

The components (dry, wet and cloud) of total atmospheric $\mathrm{S}$ and $\mathrm{N}$ deposition are presented in Figs. 15 and 16 for 2000 through 2011. Dry deposition was modeled using MLM based on filter pack concentrations obtained from the CASTNET GRS420 site (Fig. 1) and local meteorological data. The Figs. 15 and 16 show that deposition of total $\mathrm{S}$ and total $\mathrm{N}$ has decreased since 2000 with the biggest decreases in cloud deposition.

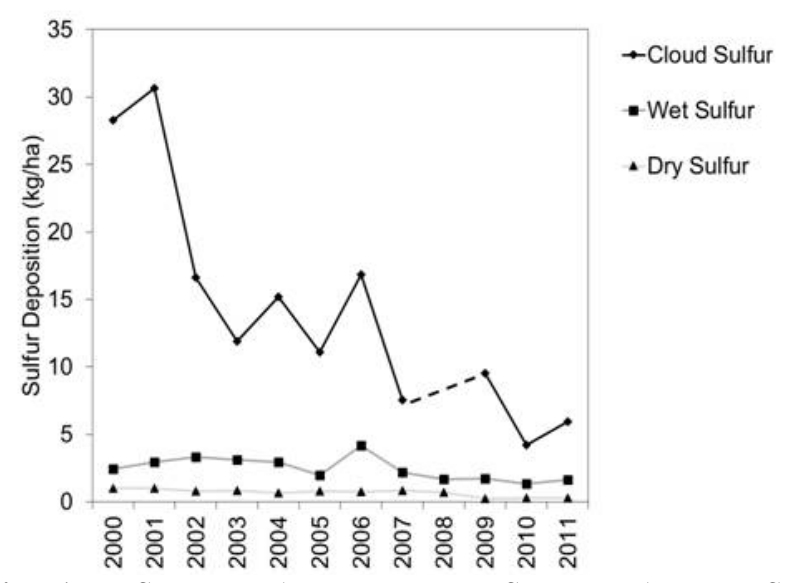

Fig. 15 Seasonal (June through September) total $\mathrm{S}$ deposition components for CLD303, 2000-2011.

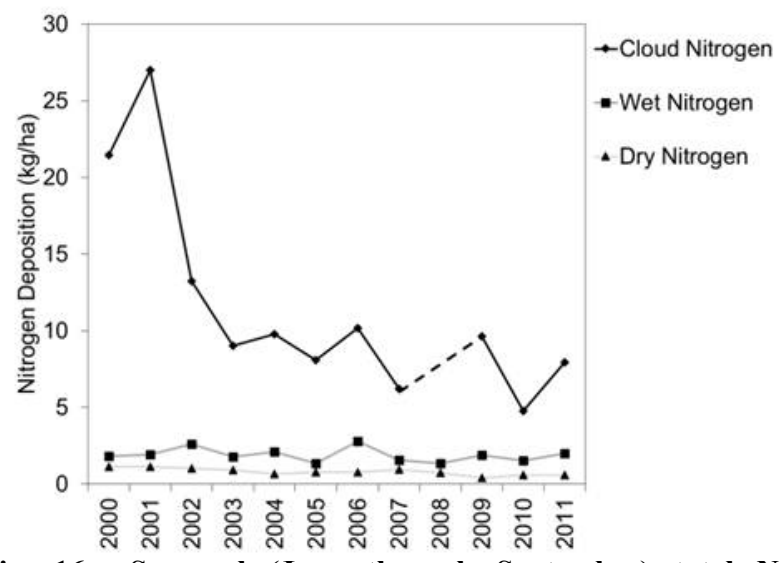

Fig. 16 Seasonal (June through September) total $N$ deposition components for CLD303, 2000-2011.

Cloud water $\mathrm{S}$ deposition decreased by 79 percent since 2000 while dry and wet $\mathrm{S}$ deposition decreased by 70 and 33 percent, respectively. Cloud water S deposition accounted for approximately 71 to 89 percent of the total $\mathrm{S}$ deposition to CLD303 from 2000 through 2011.

Cloud water $\mathrm{N}$ deposition decreased by 63 percent since 2000, and dry $\mathrm{N}$ deposition decreased by 48 percent. However, wet $\mathrm{N}$ deposition has not shown a discernible change since 2000. Cloud water $\mathrm{N}$ deposition contributed approximately 69 to 90 percent to the total $\mathrm{N}$ deposition from 2000 through 2011. It is worth noting that dry $\mathrm{N}$ deposition values estimated from CASTNET filter pack measurements do not include certain nitrogen species, most notably $\mathrm{NH}_{3}$. Even if these missing dry nitrogen species were 
accounted for, cloud water $\mathrm{N}$ deposition would still be the dominant contributor to total $\mathrm{N}$ deposition. However, the addition of $\mathrm{NH}_{3}$ and other species to the total dry $\mathrm{N}$ deposition budget would likely make the contribution from the dry component more similar to, or even greater than the contribution from the wet component.

\subsection{Changes in Cloud Water Concentrations,} Deposition Fluxes, and $\mathrm{SO}_{2}$ and $\mathrm{NO}_{x}$ Emissions

A large number of EGUs with high $\mathrm{SO}_{2}$ and $\mathrm{NO}_{\mathrm{x}}$ emissions are located along the Ohio River. $\mathrm{SO}_{2}$ and $\mathrm{NO}_{\mathrm{x}}$ emissions from electric generating plants for 2011 for Tennessee and the states surrounding CLD303 are shown in Figs. 17 and 18, respectively. Power plant emissions have been reduced significantly [30] in Tennessee and nearby states during the period 2000 through 2011 as shown in Table 1 and Figs. 19 and 20.

Dry sulfur and nitrogen species concentrations measured by filter pack sampling at the lower

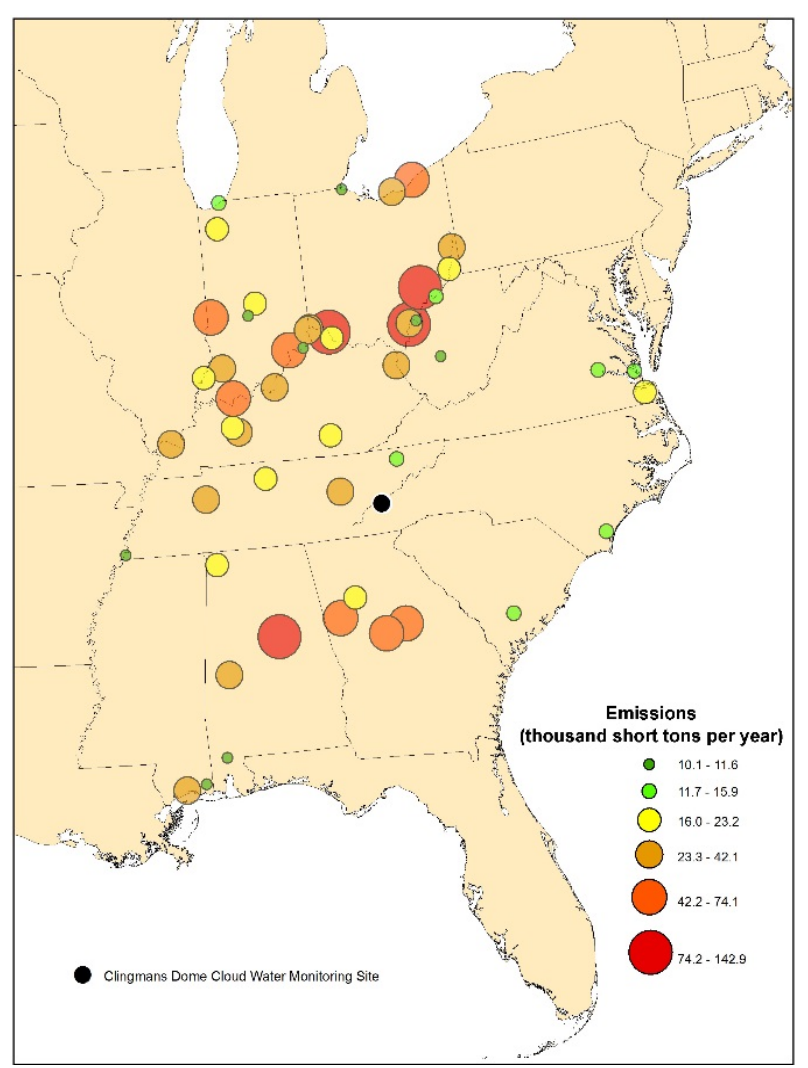

Fig. 17 Map of EGU $\mathrm{SO}_{2}$ emissions for 2011.

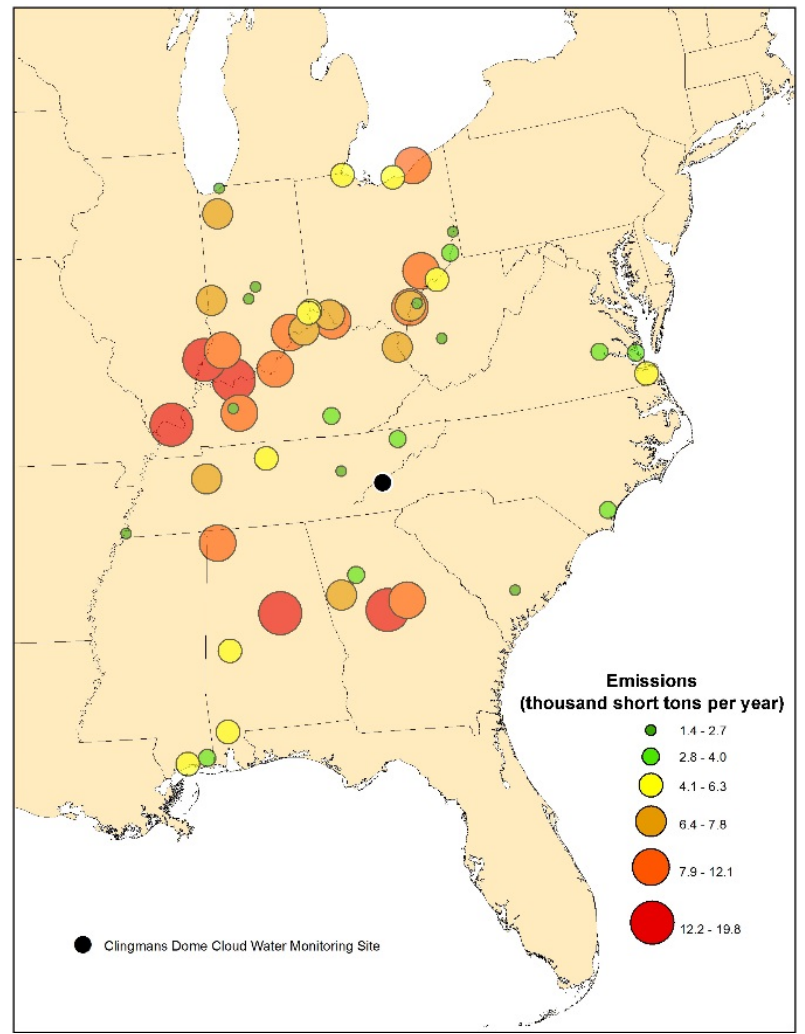

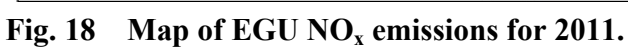

Table 1 Power plant emission reductions (percent) from 2000 through 2011 for Tennessee and nearby states.

\begin{tabular}{lll}
\hline State & $\begin{array}{l}\mathrm{SO}_{2} \text { (percent } \\
\text { reduced) }\end{array}$ & $\begin{array}{l}\mathrm{NO}_{\mathrm{x}} \text { (percent } \\
\text { reduced) }\end{array}$ \\
\hline Kentucky & 58 & 63 \\
Virginia & 69 & 64 \\
Tennessee & 72 & 83 \\
North Carolina & 84 & 74 \\
South Carolina & 67 & 73 \\
Georgia & 64 & 70 \\
Alabama & 65 & 66 \\
\hline
\end{tabular}

elevation CASTNET sites and in estimates of total (dry + wet) deposition in the eastern United States have steadily declined over the period 2000 through 2011 [31]. This same decline has also been observed in cloud water sample concentrations measured at CLD303 and in estimates of cloud water deposition for CLD303 over the period 2000 through 2011 (Figs. 19 and 20).

Emissions increased in 2010, and although emissions decreased in 2011, they were higher than 2009 levels [32]. Seasonal cloud water concentrations measured in 2007 and 2009 mirrored these emission 


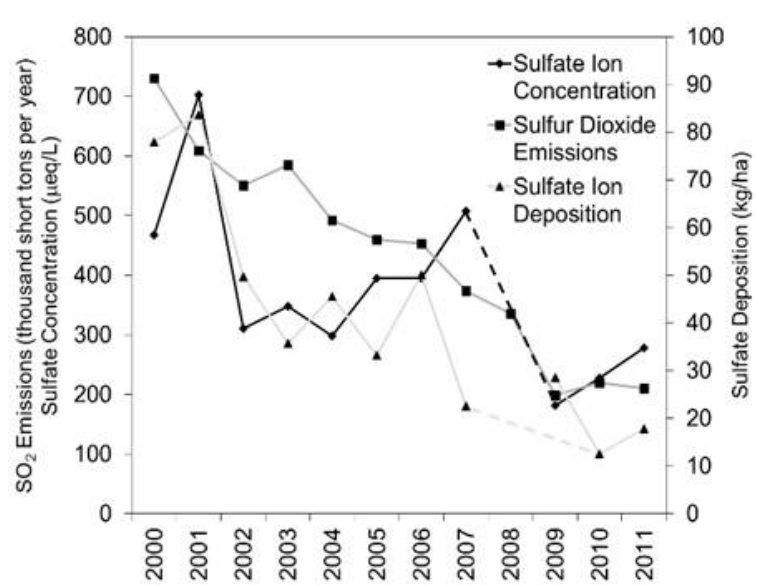

Fig. 19 Seasonal (June through September) cloud water $\mathrm{SO}_{4}{ }^{2-}$ concentrations and deposition estimates and TVA annual $\mathrm{SO}_{2}$ emissions, 2000-2011.

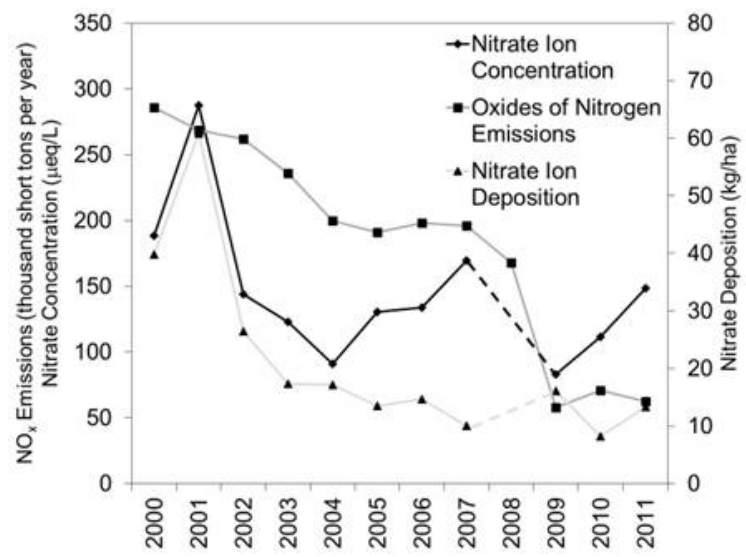

Fig. 20 Seasonal cloud water $\mathrm{NO}_{3}^{-}$concentrations and deposition estimates and TVA annual $\mathrm{NO}_{\mathrm{x}}$ emissions, 2000-2011.

reductions, as well as the increase in 2010. However, seasonal cloud water concentrations of both $\mathrm{SO}_{4}{ }^{2-}$ and $\mathrm{NO}_{3}^{-}$increased again in 2011 when emissions decreased. One possible reason for cloud water concentrations not always tracking emissions trends is the influence of cloud LWC (Fig. 5) and weather conditions, including transport patterns, cloudiness and precipitation, which can vary substantially from one collection season to another and affect the concentration of pollutants within a cloud.

\subsection{Back Trajectory Analyses of Elevated and Low $\mathrm{H}^{+}$ Concentration Events}

Fig. 21 provides an example wind rose, which was constructed from hourly wind direction and wind speed measurements collected from June 1, 2006 through September 30, 2006. Fig. 21 shows the most frequent winds were from the west through south with smaller secondary peaks from the north and north-northwest. Table 2 summarizes seasonal wind direction frequencies for the years 2000 through 2011. Table 2 shows relatively persistent wind directions from year-to-year with prevailing winds from the west-southwest through south-southwest. The frequency of winds from these three directions varied from 24.3 to 41.5 percent. Comparison of Figs. 17, 18 and 21 provides an indication of approximate source regions for pollutant deposition at CLD303 and provides a context for the measurements and analyses discussed.

Back trajectories originating at CLD303 were simulated using the HYSPLIT model [33-37] and then aggregated over cloud water sampling periods in 2000 through 2007 and 2009 through 2011. The trajectory modeling was performed in order to obtain an understanding of source (EGU $\mathrm{SO}_{2}$ and $\mathrm{NO}_{\mathrm{x}}$ ) receptor (CLD303) relationships. Cloud water concentrations were much higher during 2000 through 2007 than 2009 through 2011, so analyses were done separately for each period.

HYSPLIT used meteorological data to drive the trajectories. For this analysis, trajectories were calculated using two input data sets: (1) 2000-2007: NARR (North American Regional Reanalysis) [38] input data with 32 kilometer $(\mathrm{km})$ resolution and (2) 2009-2011: NAM12 (North American Mesoscale 12) [39] input data with $12 \mathrm{~km}$ resolution. The NARR/NAM National Centers for Environmental Prediction reanalysis data was provided by the NOAA/OAR/ESRL PSD (National Oceanic and Atmospheric Administration/Office of Oceanic and Atmospheric Research/Earth System Research Laboratory/Physical Sciences Division) website [39]. NARR has 29 vertical levels and is operated 8 times per day. NAM12 runs 4 times daily and its vertical structure and number of levels depend on the application. 


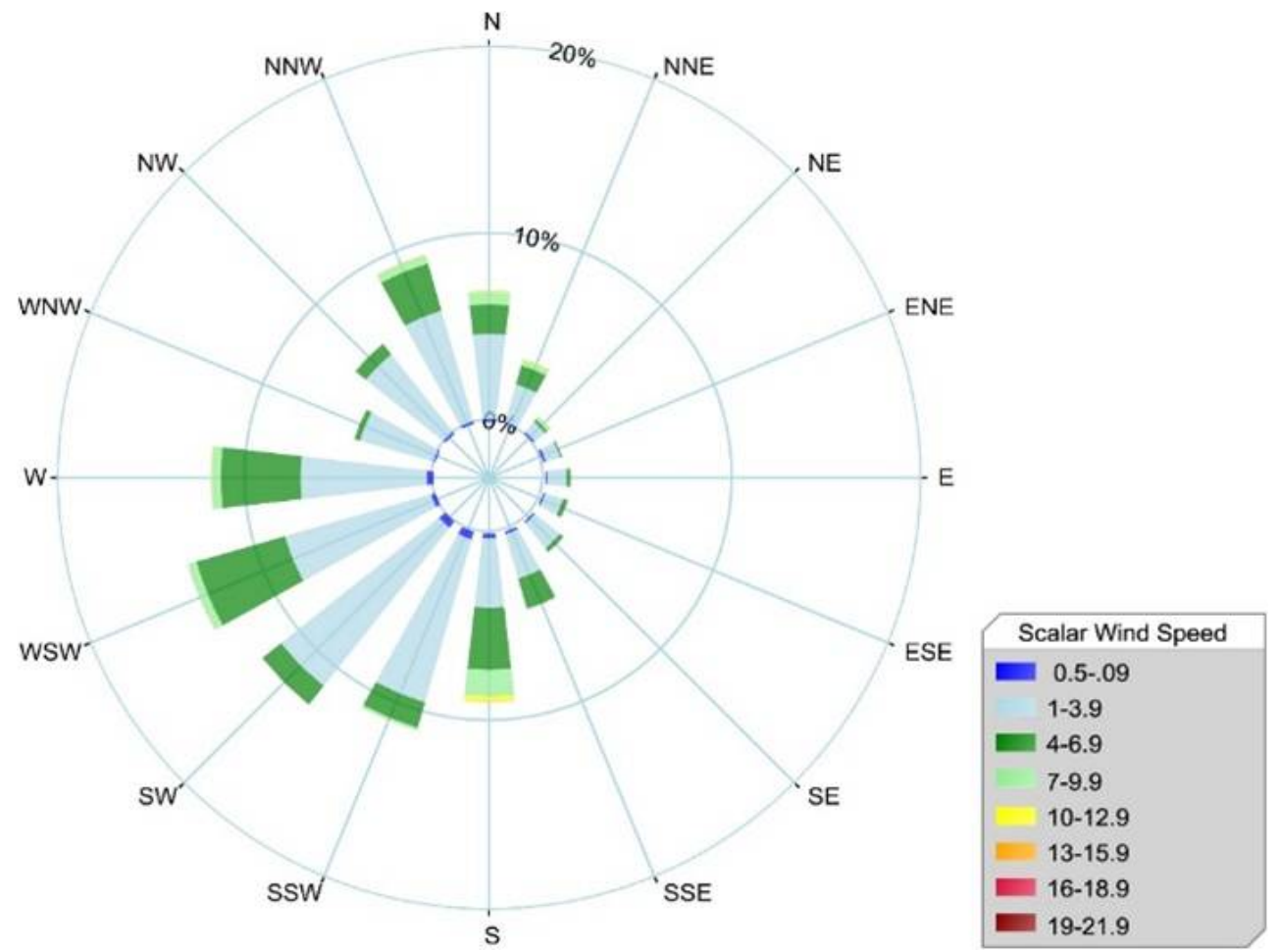

Fig. 21 Wind rose for the 2006 season (June through September).

Table 2 Summary of seasonal (June through September) wind direction frequencies (percentage), 2000-2011.

\begin{tabular}{lllllllll}
\hline Year & N & $\begin{array}{l}\text { NNE, NE, } \\
\text { ENE }\end{array}$ & E & $\begin{array}{l}\text { ESE, SE, } \\
\text { SSE }\end{array}$ & S & $\begin{array}{l}\text { SSW, SW, } \\
\text { WSW }\end{array}$ & W & $\begin{array}{l}\text { WNW, NW, } \\
\text { NNW }\end{array}$ \\
\hline 2000 & 6.35 & 5.5 & 3.01 & 9.26 & 5.15 & 35.15 & 11.48 & 24.18 \\
2001 & 7.55 & 6.79 & 1.57 & 6.32 & 7.57 & 32.17 & 13.52 & 24.51 \\
2002 & 6.17 & 6.42 & 3.57 & 13.94 & 9.48 & 27.21 & 11.03 & 22.15 \\
2003 & 5.19 & 3.37 & 0.88 & 6.48 & 7.06 & 41.50 & 12.76 & 22.65 \\
2004 & 5.50 & 7.30 & 3.48 & 14.69 & 6.47 & 30.28 & 13.57 & 18.02 \\
2005 & 10.34 & 10.65 & 3.39 & 16.47 & 8.62 & 24.26 & 9.10 & 17.16 \\
2006 & 6.97 & 5.78 & 1.35 & 7.68 & 8.97 & 37.14 & 11.82 & 19.96 \\
2007 & 7.76 & 10.22 & 2.59 & 11.07 & 5.82 & 29.12 & 13.08 & 20.29 \\
2008 & 10.17 & 9.49 & 2.74 & 12.26 & 5.67 & 29.00 & 13.08 & 17.48 \\
2009 & 6.00 & 3.88 & 0.96 & 7.14 & 9.05 & 36.89 & 17.22 & 18.82 \\
2010 & 8.18 & 6.32 & 0.87 & 8.04 & 4.21 & 29.16 & 18.06 & 25.16 \\
2011 & 11.28 & 7.46 & 0.99 & 4.95 & 5.77 & 30.65 & 17.45 & 21.31 \\
Average & 7.62 & 6.93 & 2.12 & 9.86 & 6.99 & 31.88 & 13.51 & 20.97 \\
\hline
\end{tabular}

Three-day long ensemble [33] back trajectories originated at $300 \mathrm{~m}$ above ground level. Fig. 22 shows trajectories for days with $\mathrm{H}^{+}$concentrations above the 90th percentile for 2000 through 2007. On these days, trajectories most often traveled from eastern Kentucky, northern Georgia and more locally, from eastern Tennessee. Major EGU $\mathrm{SO}_{2}$ sources were located in northeastern Kentucky along the Ohio River, central
Georgia and Alabama, and scattered throughout Tennessee (Fig. 17). EGU $\mathrm{NO}_{\mathrm{x}}$ sources were located in about the same locations with strong geographic density along the Ohio River (Fig. 18).

Days with $\mathrm{H}^{+}$concentrations above the 90th percentile for 2009 through 2011 (Fig. 23) show more detailed trajectory information because of the $12 \mathrm{~km}$ grid of the meteorological input data. The trajectories 
in Fig. 23 show that air flow passed over sources in Kentucky to the Indiana border, northern Alabama, northern Georgia and South Carolina, and across North Carolina to Virginia.

Concentrations below the 10th percentile for both periods, 2000 through 2007 (Fig. 24) and 2009 through 2011 (Fig. 25), most often originated from the Atlantic Ocean, Gulf of Mexico, or on a northward trajectory from central Ohio into southern Ontario. Again, days with low $\mathrm{H}^{+}$concentrations for 2009 through 2011 (Fig. 25) show more detailed trajectory information than for 2000 through 2007 (Fig. 24) because of the $12 \mathrm{~km}$ grid of the meteorological input data.

In summary, HYSPLIT trajectories ending at CLD303 for periods with high $\mathrm{H}^{+}$concentrations
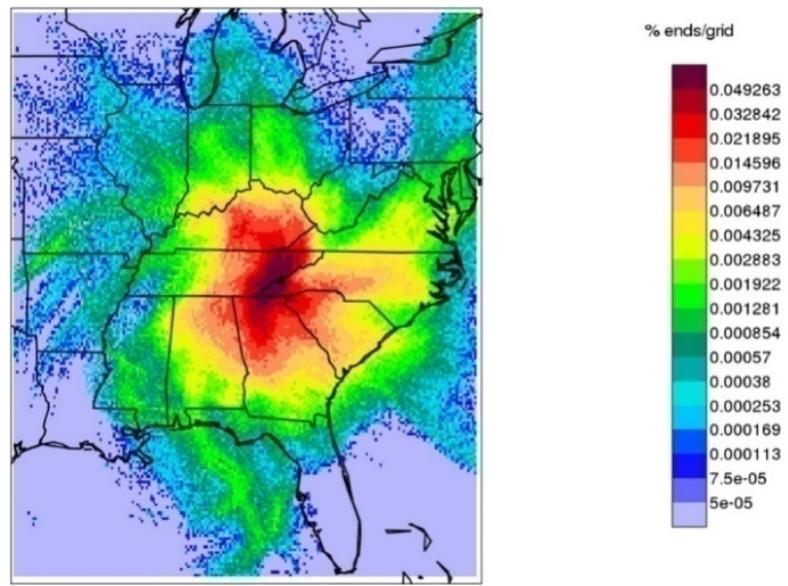

Fig. 22 Trajectories $\left(32 \mathrm{~km}\right.$ grid) for days with $\mathrm{H}^{+}$ concentrations above the 90th percentile, 2000-2007.
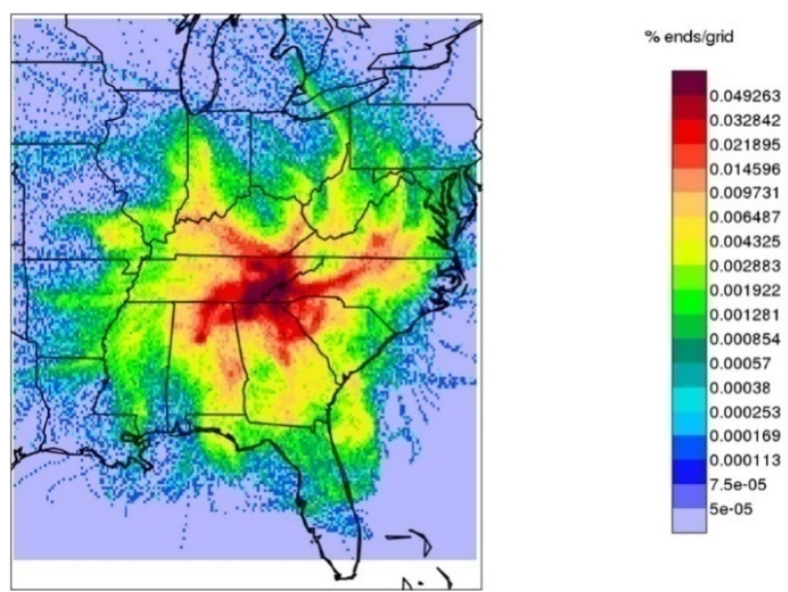

Fig. 23 Trajectories $\left(12 \mathrm{~km}\right.$ grid) for days with $\mathrm{H}^{+}$ concentrations above the 90th percentile, 2009-2011.
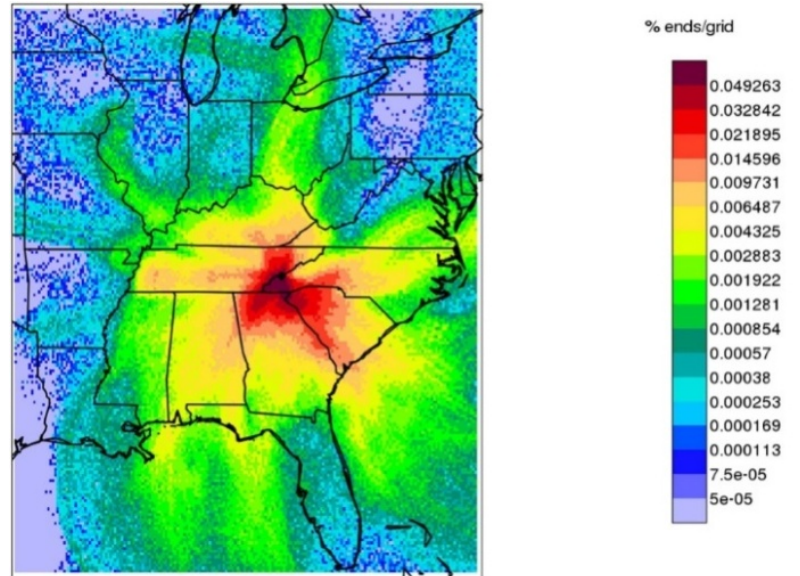

Fig. 24 Trajectories $\left(32 \mathrm{~km}\right.$ grid) for days with $\mathrm{H}^{+}$ concentrations below the 10th percentile, 2000-2007.
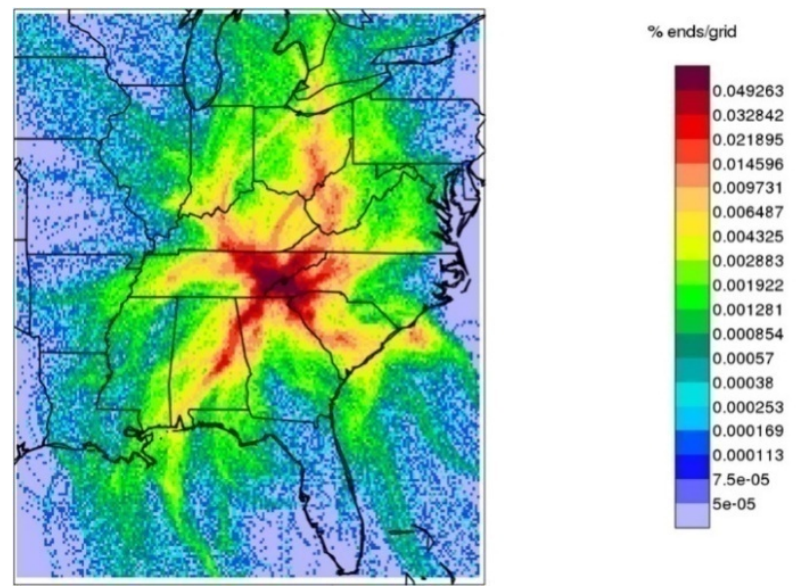

Fig. 25 Trajectories $\left(12 \mathrm{~km}\right.$ grid) for days with $\mathrm{H}^{+}$ concentrations below the 10th percentile, 2009-2011.

traveled over EGU sources locally in Tennessee, Kentucky to the Ohio River Valley, Alabama and Georgia. These source regions contributed to acidic cloud water deposition at CLD303.

\section{Summary and Conclusions}

Cloud frequency and LWC values varied substantially from month-to-month and year-to-year during the course of this project. The variance in LWC values correlated well with the variance in annual precipitation, but the range of variance in precipitation values was greater than for the LWC values. The prevailing winds during the sampling months were from the west-southwest with smaller secondary peaks from the north and north-northwest. The direction of the prevailing winds suggests transport from known 
source regions with subsequent cloud pollutant deposition in the Great Smokies.

Cloud water concentrations of the major ions of $\mathrm{SO}_{4}{ }^{2-}, \mathrm{NO}_{3}{ }^{-}, \mathrm{NH}_{4}^{+}$and $\mathrm{H}^{+}$showed a general decreasing trend after 2001. The exception to this decreasing trend was the 3-year period from 2005 through 2007 when all major ion concentrations, except for $\mathrm{H}^{+}$, increased. Regardless of the inter-annual variations in concentrations, the 3-year mean concentrations of $\mathrm{SO}_{4}{ }^{2-}, \mathrm{NO}_{3}{ }^{-}, \mathrm{NH}_{4}{ }^{+}$and $\mathrm{H}^{+}$ from 2009 through 2011 were lower by 49, 39, 12 and 88 percent, respectively, compared to the 3 -year mean concentrations from 2000 through 2002. Precipitation concentrations at the NADP/NTN site TN11 followed the same general pattern of increases and decreases as cloud water concentrations, especially after 2004.

Comparison of the CLD303 data with data from the cloud water monitoring site WFM300 shows that seasonal LWC values at WFM300 were consistently higher. The 12-year average LWC value at WFM300 was almost twice as high as the average value at CLD303. The $\mathrm{SO}_{4}{ }^{2-}$ and $\mathrm{NO}_{3}{ }^{-}$concentrations were consistently higher at CLD303 by 45 and 44.5 percent, respectively. The overall downward trend in concentrations observed at CLD303 was also evident at WFM300.

Cloud water deposition estimated by the CLOUD model showed declines in 3-year average deposition estimates of 71, 70, 49 and 88 percent for $\mathrm{SO}_{4}{ }^{2-}, \mathrm{NO}_{3}{ }^{-}$, $\mathrm{NH}_{4}^{+}$and $\mathrm{H}^{+}$, respectively, from 2000-2002 to 2009-2011. Comparison with wet deposition data from TN11 show that $\mathrm{SO}_{4}{ }^{2-}$ deposition estimates for cloud water and precipitation follow a similar pattern from 2004 onward. The $\mathrm{NO}_{3}^{-}$deposition estimates were more variable.

Cloud water S deposition accounted for 71 to 89 percent of the total deposition (cloud, wet and dry) with cloud water $\mathrm{N}$ deposition composing approximately 69 to 90 percent of the total deposition. All three components of total deposition showed a decrease since 2000 for $\mathrm{SO}_{4}{ }^{2-}$. $\mathrm{N}$ deposition estimates also decreased for the cloud water and dry components, but there has been no discernible change in the wet $\mathrm{N}$ component since 2000 .

TVA reported that emissions from TVA-operated power plants generally declined from 2000 through 2011 with some exceptions, such as 2010, when emissions increased. Cloud water concentration and deposition trends for $\mathrm{SO}_{4}{ }^{2-}$ and $\mathrm{NO}_{3}{ }^{-}$generally mirror the emission trends for $\mathrm{SO}_{2}$ and $\mathrm{NO}_{\mathrm{x}}$. However, there are exceptions. For example, in 2011 emissions decreased but both concentrations and deposition estimates increased. A possible reason for such exceptions may be the influence of cloud LWC and weather conditions, which usually vary from season-to-season and can affect the concentrations of pollutants within a cloud.

The HYSPLIT model was used to simulate back trajectories originating at CLD303 and aggregated over cloud sampling periods from 2000 through 2007 and 2009 through 2011. These analyses showed that trajectories ending at CLD303 during periods with high $\mathrm{H}^{+}$concentrations traveled over local EGU emission sources in Tennessee and Kentucky to the Ohio River Valley, Alabama and Georgia with the conclusion that these source regions contributed to acidic cloud water deposition at CLD303.

Disclaimer: the assumptions, findings, conclusions, judgments and views presented herein are those of the authors and should not be interpreted as necessarily representing official National Park Service policies.

\section{References}

[1] Amec Foster Wheeler Environment \& Infrastructure, Inc. 2012. Cloud Deposition Monitoring; Clingmans Dome, TN; Great Smoky Mountains National Park 2011. Accessed May 23, 2017. https://www3.epa.gov/castnet/docs/Annual_Report_Cling mans_Dome_2011.pdf.

[2] Isil, S., Lavery, T. F., Baumgardner, R., Mohnen, V., Miller, E., Lovett, G., et al. 2000. "Mountain Acid Deposition Program (MADPro): Cloud Deposition to the Appalachian Mountains, 1994-1999." Rep. EPA/600/R-01: 16. 
[3] Mohnen, V. A., and Vong, R. J. 1993. "A Climatology of Cloud Chemistry for the Eastern United States Derived from the Mountain Cloud Chemistry Project." Environ. Rev. 1 (1): 38-54.

[4] Mohnen, V. A., Aneja, V., Bailey, B., Cowling, E., and Goltz, S. M. 1990. Assessment of Atmospheric Exposure and Deposition to High-elevation Forests in the Eastern United States. Report EPA/600/3-90/058. State Univ. of New York, Albany, NY (USA). Atmospheric Sciences Research Center.

[5] Vong, R. J., Sigmon, J. T., and Mueller, S. F. 1991. "Cloud Water Deposition to Appalachian Forests." Environmental Science and Technology 25 (6): 1014-21.

[6] Aneja, V. P., and Kim, D. S. 1993. "Chemical Dynamics of Clouds at Mt. Mitchell, North Carolina." Air \& Waste 43 (8): 1074-83.

[7] Miller, E. K., Panek, J. A., Friedland, A. J., Kadlecek, J., and Mohnen, V. A. 1993. "Atmospheric Deposition to a High-elevation Forest at Whiteface Mountain, New York, USA." Tellus B 45 (3): 209-27.

[8] Lindberg, S. E. 1992. "Atmospheric Deposition and Canopy Interactions of Sulfur." Atmospheric Deposition and Forest Nutrient Cycling: A Synthesis of the Integrated Forest Study. Ecological Studies 91: 74-89.

[9] Lovett, G. M., and Kinsman, J. D. 1990. "Atmospheric Pollutant Deposition to High-elevation Ecosystems." Atmospheric Environment. Part A. General Topics 24 (11): 2767-86.

[10] Miller, E. K., and Friedland, A. J. 1999. "Local Climate Influences on Precipitation, Coud Water, and Dry Deposition to an Adirondack Subalpine Forest: Insights from Observations 1986-1996." Journal of Environmental Quality 28 (1): 270-7.

[11] Eager, C., Adams, M. B., Johnson, A. H., McLaughlin, S. B., Cook, E. R., De-Hayes, D. H., et al. 1992. "Ecology and Decline of Red Spruce in the Eastern United States." Springer-Verlag, New York 96: 385-411.

[12] United Kingdom's National Meteorological Service. 2015. The Great Smog of 1952. Accessed July 28, 2016. $\mathrm{http} / / /$ www.metoffice.gov.uk/learning/learn-about-the-we ather/weather-phenomena/case-studies/great-smog.

[13] Mohnen, V. A., and Kadlecek, J. A. 1989. "Cloud Chemistry Research at Whiteface Mountain." Tellus B 41 (1): 79-91.

[14] Saxena, V. K., Stogner, R. E., Hendler, A. H., Felice, T. P., Yeh, R. Y., and Lin, N. H. 1989. "Monitoring the Chemical Climate of the Mt. Mitchell State Park for Evaluation of Its Impact on Forest Decline." Tellus B 41 (1): 92-109.

[15] Li, Z., and Aneja, V. P. 1992. "Regional Analysis of Cloud Chemistry at High Elevations in the Eastern United States." Atmospheric Environment. Part A.
General Topics 26 (11): 2001-17.

[16] Nilsson, J. 1988. "Critical Loads for Sulphur and Nitrogen." In Air Pollution and Ecosystems: 85-91. Springer Netherlands.

[17] Pardo, L. H. 2010. "Approaches for Estimating Critical Loads of $\mathrm{N}$ and $\mathrm{S}$ Deposition for Forest Ecosystems on U.S. Federal Lands." Gen. Tech. Rep. NRS-71. Newtown Square, PA: U.S. Department of Agriculture, Forest Service, Northern Research Station.

[18] National Atmospheric Deposition Program. 2017. TDEP: Total Deposition Science Committee. Accessed May 23, 2017. http://nadp.sws.uiuc.edu/committees/tdep/.

[19] National Atmospheric Deposition Program. 2017. CLAD: Critical Loads of Atmospheric Deposition Science Committee. Accessed May 23, 2017. http://nadp.sws.uiuc.edu/committees/clad/.

[20] Lovett, G. M. 1984. "Rates and Mechanisms of Cloud Water Deposition to a Subalpine Balsam Fir Forest." Atmospheric Environment 18 (2): 361-71.

[21] Meyers, T. P., Finkelstein, P., Clarke, J., Ellestad, T. G., and Sims, P. F. 1998. "A Multilayer Model for Inferring Dry Deposition Using Standard Meteorological Measurements." J. Geophys. Res. Atmos. 103 (D17): 22645-61.

[22] Finkelstein, P. L., Ellestad, T. G., Clarke, J. F., Meyers, T. P., Schwede, D. B., Hebert, E. O., et al. 2000. "Ozone and Sulfur Dioxide Dry Deposition to Forests: Observations and Model Evaluation.” J. Geophys. Res. Atmos. 105 (D12): 15365-77.

[23] Baumgardner, R. E., Kronmiller, K. G., Anderson, J. B., Bowser, J. J., and Edgerton, E. S. 1997. "Development of an Automated Cloud Water Collection System for Use in Atmospheric Monitoring Networks." Atmospheric Environment 31 (13): 2003-10.

[24] Gerber, H. 1984. "Liquid Water Content of Fogs and Hazes from Visible Light Scattering." Journal of Climate and Applied Meteorology 23 (8): 1247-52.

[25] Anlauf, K. G., Wiebe, H. A., and Fellin, P. 1986. "Characterization of Several Integrative Sampling Methods for Nitric Acid, Sulfur Dioxide and Atmospheric Particles." JAPCA 36 (6): 715-23.

[26] Amec Foster Wheeler Environment \& Infrastructure, Inc. 2015. CASTNET Quality Assurance Project Plan (QAPP) Revision 8.3. Accesssed January 31, 2016. https://java.epa.gov/castnet/documents.do.

[27] Lovett, G. M., and Reiners, W. A. 1986. "Canopy Structure and Cloud Water Deposition in Subalpine Coniferous Forests." Tellus B 38 (5): 319-27.

[28] Thorne, P. G., Lovett, G. M., and Reiners, W. A. 1982. "Experimental Determination of Droplet Impaction on Canopy Components of Balsam Fir." J. Appl. Meteorol. 21 (10): 1413-6. 


\section{Magnitude and Trends of High-elevation Cloud Water Pollutant Concentrations and Modeled Deposition Fluxes}

[29] Adirondack Lake Survey Corporation. 2014. Whiteface Mountain Cloud Monitoring Data for 2002 through 2011. Adirondack Lakes Survey Corporation, Raybrook, New York. Accessed June 6, 2016. http://www.adirondacklakessurvey.org/wfc.shtml.

[30] U.S. Environmental Protection Agency. 2016. Clean Air Markets 2014 Progress Report. Accessed May 10, 2017. https:/www3.epa.gov/airmarkets/progress/reports/emissi ons_reductions_so2.html\#Fig.1.

[31] Amec Foster Wheeler Environment \& Infrastructure, Inc. 2013. Clean Air Status and Trends Network (CASTNET) 2011 Annual Report. Accessed June 6, 2016. https://java.epa.gov/castnet/documents.do.

[32] Tennessee Valley Authority. 2012. Air Quality. Accessed October

2012. http://www.tva.com/environment/air/index.htm.

[33] Stein, A. F., Draxler, R. R, Rolph, G. D., Stunder, B. J., Cohen, M. D., and Ngan, F. 2015. "NOAA's HYSPLIT Atmospheric Transport and Dispersion Modeling System." Bull. Amer. Meteor. Soc. 96 (12): 2059-77.

[34] Draxler, R. R. 1999. HYSPLIT4 User's Guide. NOAA Air
Resources Laboratory, Silver Spring, MD. NOAA Tech. Memo.

[35] Draxler, R. R., and Hess, G. D. 1998. "An Overview of the HYSPLIT 4 Modeling System for Trajectories." Aust. Meteor. Mag. 47 (4): 295-308.

[36] Draxler, R. R., and Hess, G. D. 1997. "Description of the HYSPLIT 4 Modeling System." NOAA Tech. Memo. ERL ARL-224.

[37] Rolph, G. D. 2016. Real-time Environmental Applications and Display System (READY). NOAA Air Resources Laboratory, Silver Spring, Maryland. Accessed May 23, 2017. http://ready.arl.noaa.gov.

[38] Mesinger, F., DiMego, G., Kalnay, E., Mitchell, K., Shafran, P. C., Ebisuzaki, W., et al. 2006. "North America Regional Reanalysis." Bulletin of the American Meteorological Society 87 (3): 343-60.

[39] National Oceanic and Atmospheric Administration. 2015. National Centers for Environmental Prediction (NCEP). Reanalysis Data. NOAA/OAR/ESRL PSD, Boulder, Colorado. Accessed May 23, 2017. http://www.esrl.noaa.gov/psd/. 